\title{
The Use of Google Classroom in Facial Skin Care Courses with Technology
}

\author{
Hasri Mutiara Putri ${ }^{1}$, Aniesa Puspa Arum ${ }^{2}$, Neneng Siti Silfi Ambarwati ${ }^{3}$ \\ ${ }^{1}$ Universitas Negeri Jakarta, Jl. Rawamangun Muka Raya, Jakarta Timur, Indonesia \\ tiamutiaraputri99@gmail.com \\ ${ }^{2}$ Universitas Negeri Jakarta, Jl. Rawamangun Muka Raya, Jakarta Timur, Indonesia \\ aniesa.puspa@gmail.com \\ ${ }^{3}$ Universitas Negeri Jakarta, Jl. Rawamangun Muka Raya, Jakarta Timur, Indonesia \\ neneng_ambarwati@yahoo.co.id
}

\begin{abstract}
Learning outcomes are a learning carried out by someone after going through the process of learning activities, which uses an assessment tool prepared by the teacher, such as an evaluation test that includes cognitive, affective and psychomotor aspects. This study aims to determine the relationship between student interest in the use of Google Classroom with learning outcomes of facial skin care with technology. This research is a quantitative research with a survey method with a sample of 65 students of the Cosmetology Education study program batch 2020 . The data for the $\mathrm{X}$ variable (student interest in using Google Classroom) was obtained by distributing questionnaires with a Likert scale. Meanwhile, the Y variable data (Learning Results of Facial Skin Care with Technology) was obtained from Form 06. The results of the analysis with product moment correlation showed that there was no positive and significant relationship between students' interest in learning outcomes of facial skin care with technology. Based on the calculations obtained a significance value of 0.274 which means it is greater than 0.05 . So it can be concluded that Ho which reads: "Students' Interest in Using Google Classroom does not have a positive effect on Learning Outcomes of Facial Skin Care with Technology" is accepted. On the other hand, "Students' Interest in Using Google Classroom has a positive effect on Learning Outcomes of Facial Skin Care with Technology" is rejected. The effective contribution was obtained by $1.9 \%$ and the remaining $98.1 \%$ was not examined in this study.
\end{abstract}

Keywords: google classroom, courses, facial skin care, technology

Copyright (C) 2021 The Author(s)

This is an open-access article under the CC BY-SA license. 


\title{
Penggunaan Google Classroom pada Mata Kuliah Perawatan Kulit Wajah dengan Teknologi
}

\begin{abstract}
Abstrak
Hasil belajar adalah suatu pembelajaran yang dilakukan oleh seseorang setelah melalui proses kegiatan belajar, dimana menggunakan suatu alat penilaian yang disusun oleh pengajar, seperti tes evaluasi yang meliputi aspek kognitif, afektif dan psikomotor. Penelitian ini bertujuan untuk mengetahui hubungan minat mahasiswa dalam penggunaan Google Classroom dengan hasil belajar perawatan kulit wajah dengan teknologi. Penelitian ini merupakan penelitian kuantitatif dengan metode survei dengan jumlah sampel 65 mahasiswa program studi Pendidikan Tata Rias angkatan 2020. Data untuk variabel X (minat mahasiswa dalam penggunaan Google Classroom) didapat dengan cara penyebaran kuesioner dengan skala likert. Sedangkan, data variabel Y (hasil belajar Perawatan Kulit Wajah dengan Teknologi) didapat dari Form 06. Hasil analisis dengan korelasi product momen menunjukkan tidak terdapat hubungan positif dan signifikan antara minat mahasiswa terhadap hasil belajar perawatan kulit wajah dengan teknologi. Berdasarkan perhitungan diperoleh nilai signifikansi sebesar 0,274 yang berarti lebih besar dari pada 0,05. Sehingga dapat disimpulkan bahwa Ho yang berbunyi: "Minat Mahasiswa Dalam Penggunaan Google Classroom tidak berpengaruh positif terhadap Hasil Belajar Perawatan Kulit Wajah dengan Teknologi" diterima. Sebaliknya, "Minat Mahasiswa Dalam Penggunaan Google Classroom berpengaruh positif terhadap Hasil belajar Perawatan Kulit Wajah dengan Teknologi" ditolak. Sumbangan efektif diperoleh sebesar $1,9 \%$ dan sisanya $98,1 \%$ tidak diteliti dalam penelitian ini.
\end{abstract}

Kata kunci: google classroom, mata kuliah, perawatan kulit wajah, teknologi

\section{PENDAHULUAN}

Mudahnya penularan virus corona antar manusia ataupun hewan menimbulkan pemerintah membuat sebagian kebijakan buat menghentikan penyebaran wabah ini. Semacam melaksanakan lockdown (kebijakan pembatasan secara ketat aktivitas dan mobilitas warga di suatu daerah) di wilayah yang tercantum dalam zona merah penyebaran virus, setelah itu physical quarantine buat menjauhi penyebaran virus secara kontak raga (Nurkholis, 2020:40).

Virus ini berakibat pada bermacam bidang kehidupan, salah satunya merupakan bidang pembelajaran. Pemerintah menghasilkan kebijakan buat melaksanakan pendidikan via daring ataupun bisa pula diucap Pendidikan Jarak Jauh (PJJ) mulai dari jenjang halaman anak- anak sampai akademi besar. Sedangkan itu, harus diketahui pembelajaran ialah perihal yang berarti sehingga 
dipaparkan serta diatur dalam UU Nomor. 20 Tahun 2003 Tentang Pembelajaran Nasional (SISDIKNAS) (Darmawani, 2015:2).

Virus corona memberikan dampak dalam bidang pembelajaran salah satunya ialah terbatasnya mungkin pendidikan tatap muka sehingga dilaksanakannya Pendidikan Jarak Jauh (PJJ). UNESCO (United Nations Educational, Scientific and Cultural Organization) pada 4 Maret 2020 menganjurkan pendidikan jarak jauh serta membuka platform pembelajaran yang bisa digunakan sekolah serta pengajar buat menjangkau mahasiswa dari jarak jauh serta menghalangi gangguan pembelajaran (Setiawan, 2020: 29).

Marasmita (2019:2), menyimpulkan bahwa salah satu pemakaian IPTEK dalam bidang pembelajaran ialah dengan pemakaian media pendidikan. Aktivitas pendidikan mempunyai komponen yang ada di dalamnya ialah pengajar serta mahasiswa, tidak hanya kedua nya komponen yang lain adalah media. Media merupakan perlengkapan yang dipergunakan buat mengirimkan pesan dari pengajar kepada mahasiswa ataupun pesan dari mahasiswa kepada pengajar serta pula isi modul yang sudah diberikan pengajar buat mahasiswa. Marasmita (2019:2), menerangkan bahwa media pendidikan merupakan media yang digunakan dalam pendidikan tercantum perlengkapan bantu pengajar dalam mengajar serta fasilitas penyampaian pesan dari sumber belajar kepada penerima pesan (mahasiswa).

Pemerintah mengambil kebijakan pendidikan secara daring. Akibatnya terdapat aktivitas pengajaran di sekolah serta akademi besar dialihkan ke pendidikan jarak jauh lewat aplikasi berbasis pendidikan. Fauzan et. al. (2020:94), perihal ini nampak dengan pemakaian platform pendidikan berbasis daring yang lumayan diminati oleh pengajar sejenis pemakaian Edmodo, Schoology serta Google Classroom. Wartini (2012:8), atensi merupakan indikasi psikologis yang menampilkan kalau atensi terdapatnya penafsiran subjek terhadap objek yang jadi sasaran sebab objek tersebut menarik atensi serta memunculkan perasaan bahagia sehingga cenderung kepada objek tersebut. Terdapatnya ketertarikan seorang terhadap suatu sebab tersebut sanggup memunculkan perasaan bahagia.

Fauzan et. al. (2020:95), pemakaian Google Classroom bermanfaat buat memudahkan pengajar dalam mengelola pendidikan serta mengantarkan data secara pas serta akurat kepada mahasiswa. Setelah itu, pendidikan daring tidak hendak berlangsung dengan baik bila ada kasus yang terdapat di dalamnya. Kasus tersebut dapat terjalin dari sebagian perihal baik dari pendidik, bahan ajar serta media, dan dari mahasiswa itu sendiri. Kasus dari pendidik dapat dari metode 
ataupun tata cara pendidikan yang digunakan. Kasus dari bahan ajar serta media terjalin sebab kurang sesuai nya antara modul dengan media yang digunakan. Kasus dari mahasiswa kurang tertariknya dalam modul pelajaran serta motivasi diri dalam belajar.

Pemakaian aplikasi tersebut juga digunakan dalam pendidikan di akademi besar. Salah satu akademi besar yang memakai aplikasi tersebut merupakan Universitas Negara Jakarta. Universitas tersebut salah satunya ialah dengan pemakaian aplikasi Google Classroom. Berikut merupakan hasil survei pada 65 mahasiswa Pembelajaran Tata Rias angkatan 2020 yang diambil pada bulan Juni 2021 memakai website aplikasi Google Form:

Tabel 1. Hasil Nilai Survei Aplikasi yang Sering Digunakan dalam Pembelajaran

\begin{tabular}{|c|c|c|c|}
\hline No. & Mata Kuliah & $\begin{array}{l}\text { Aplikasi yang } \\
\text { Sering } \\
\text { Digunakan }\end{array}$ & Persentase \\
\hline 1. & Agama & Zoom & $73,4 \%$ \\
\hline 2. & Bahasa Indonesia & $L M S$ & $71,9 \%$ \\
\hline 3. & Pengembangan Peserta Didik & Zoom & $71,9 \%$ \\
\hline 4. & Sejarah Mode & Zoom & $85,9 \%$ \\
\hline 5. & $\begin{array}{l}\text { Pengantar Ilmu } \\
\text { Keluarga }\end{array}$ & Edlink & $95,3 \%$ \\
\hline 6. & $\begin{array}{l}\text { Higiene Sanitasi Lingkungan dan } \\
\text { K3 }\end{array}$ & Zoom & $56,3 \%$ \\
\hline 7. & Perencanaan Pembelajaran & Zoom & $50 \%$ \\
\hline 8. & $\begin{array}{l}\text { Perawatan Kulit Wajah dengan } \\
\text { Teknologi }\end{array}$ & Google Classroom & $93,8 \%$ \\
\hline 9. & Kosmetika Bahan Alam & Zoom & $57,8 \%$ \\
\hline 10. & Tata Rias Wajah & WhatsApp & $64,1 \%$ \\
\hline 11. & Perawatan Badan & Edlink & $76,6 \%$ \\
\hline
\end{tabular}

Pencapaian hasil belajar ialah bagian terutama dalam pendidikan. Windayani \& Ihsani (2014:2), hasil belajar ialah keahlian yang dipunyai mahasiswa sehabis menerima pengalaman belajar. Aspek hasil belajar terdiri dari aspek kognitif, aspek afektif, serta aspek psikomotor. Buat menggapai pencapaian pembelajaran yang memuaskan, mahasiswa wajib menghasilkan atmosfer belajar yang efektif serta mengasyikkan. Belajar secara efektif bisa tercapai apabila mahasiswa tersebut bisa memakai strategi belajar yang pas sehingga bisa menolong dalam proses belajar. Strategi belajar dibutuhkan oleh mahasiswa supaya bisa mengendalikan waktu seefisien mungkin dan bisa memilah system belajar yang cocok dengan bidangnya. 


\section{METODE PENELITIAN}

Riset ini ialah riset kuantitatif dengan tata cara survei dengan jumlah ilustrasi 65 mahasiswa program riset Pembelajaran Tata Rias angkatan 2020. Dalam pengambilan ilustrasi, periset memakai sampling jenuh ialah metode penentuan gambaran apabila seluruh anggota populasi digunakan sebagai gambaran.

Arikunto (2012:104), menyarankan jika subjek kurang dari 100 maka jumlah tersebut bisa diambil sebagai contoh, sehingga penelitiannya jadi riset populasi. Hingga ilustrasi dalam riset ini merupakan segala mahasiswa yang saat ini sedang mengambil mata kuliah perawatan kulit wajah dengan teknologi berjumlah 65 mahasiswa yang dibagi dalam 2 kelas yang terdiri dari tahap 1 serta tahap 2 .

Informasi dikumpulkan lewat penyebaran angket (kuesioner). Angket (kuesioner) sendiri ialah metode mengumpulkan informasi yang dicoba dengan metode memberikan seperangkat persoalan tertulis kepada responden (Sugiyono, 2016:199). Angket yang digunakan dalam riset ini buat mengukur atensi mahasiswa.

Informasi yang digunakan merupakan informasi primer serta informasi sekunder. Informasi primer adalah informasi yang diperoleh secara langsung dari sumber informasi dengan observasi langsung. Sebaliknya, informasi sekunder merupakan informasi pendukung yang diperoleh dari sumber lain yang ataupun melalui perantara lain yang berkaitan dengan riset (Sugiyono, 2016:224). Informasi utama diperoleh dari angket yang digunakan buat mengenali atensi mahasiswa. Sedangkan itu, buat mengukur hasil belajar, informasi diperoleh lewat informasi sisa. Informasi bantu yang digunakan merupakan Tabel 06, yang merinci skor Tugas 1 (30\%), Paper ( 15\%), UTS ( 25\% ), UAS ( 30\%).

Instrument kuesioner digunakan buat mendapatkan hasil variabel yang pengaruhi (X) ialah atensi mahasiswa dalam pemakaian Google Classroom. Instrument riset diatas dicoba buat mengetahui informasi tentang atensi mahasiswa. Kuesioner disebar lewat Google Form kepada 65 responden secara serentak. Sebaliknya hasil belajar diperoleh dari gabungan nilai UTS, UAS, praktek setiap hari serta makalah/ tugas. Pada riset ini mempunyai 5 alternatif jawaban yang bisa diseleksi oleh responden, ialah: Sangat Sepakat (SS), Sepakat (S), Raguragu/ Netral (N), Tidak Sepakat (TS) serta Sangat Tidak Sepakat (STS) dengan skor selaku berikut. 
Tabel 2. Alternatif Jawaban dengan Skala Likert

\begin{tabular}{|l|c|c|}
\hline \multirow{2}{*}{$\begin{array}{c}\text { Alternatif } \\
\text { Jawaban }\end{array}$} & \multicolumn{2}{c|}{ Skor Item } \\
\cline { 2 - 3 } & Favorable & Unfavorable \\
\hline SS (Sangat Setuju) & 5 & 1 \\
\hline S (Setuju) & 4 & 2 \\
\hline N (Netral) & 2 & 3 \\
\hline TS (Tidak Setuju) & 1 & 4 \\
\hline STS (Sangat Tidak Setuju) & 2 & 5 \\
\hline
\end{tabular}

Sumber : (Sugiyono, 2016)

\section{HASIL DAN PEMBAHASAN}

\section{Hasil Penelitian}

Riset ini memakai informasi primer serta informasi sekunder. Informasi primer berbentuk kuesioner dicoba dibuat dalam memperoleh informasi tentang atensi mahasiswa. Sebaliknya informasi sekunder diperoleh dari gabungan nilai UTS, UAS, praktek setiap hari serta makalah/ tugas buat mendapatkan informasi tentang hasil belajar.

Sehabis informasi tentang atensi didapatkan, dicoba uji validitas serta reliabilitas. Hasil uji validitas pada kuesioner menampilkan dari 40 statement, ada 6 statement tidak valid sebab $r$ hitung \& $r$ tabel $(0,361)$ sehingga statement tersebut dibuang, setelah itu ada 34 statement valid, statement inilah yang hendak digunakan buat analisis berikutnya.

Tabel 3. Hasil Uji Reliabilitas

\begin{tabular}{|c|c|c|}
\hline Variabel & $\begin{array}{c}\text { Alpha } \\
\text { Cronbach }\end{array}$ & Keterangan \\
\hline $\begin{array}{c}\text { Minat } \\
\text { Mahasiswa }\end{array}$ & 0,961 & Reliabel \\
\hline
\end{tabular}

Berdasarkan tabel diatas, variabel penelitian Minat Mahasiswa memiliki nilai Cronbach Alpha sebesar 0,961 dimana angka tersebut berada pada nilai diatas 0,600. Sehingga variabel tersebut reliabel atau dapat dipercaya sebagai alat ukur variabel dengan tingkat korelasi sangat tinggi.

\section{Uji Prasyarat Analisis}

\section{Uji Normalitas}

Hasil normalitas untuk masing-masing variabel penelitian disajikan berikut ini:

Tabel 4. Uji Normalitas

\begin{tabular}{|l|c|c|}
\hline \multicolumn{1}{|c|}{ Variabel } & Signifikansi & Keterangan \\
\hline $\begin{array}{l}\text { Minat Mahasiswa (X) } \\
\text { terhadap Hasil Belajar } \\
\text { (Y) }\end{array}$ & 0,089 & Normal \\
\hline
\end{tabular}


Dalam pengambilan keputusan uji normalitas, seandainya nilai signifikansi > 0,05 maka data berdistribusi normal. Sebaliknya, jika nilai signifikansi < 0,05 maka data tidak berdistribusi normal. Dari penilaian uji normalitas pada tabel 4 ditemukan bahwa nilai signifikansi 0,089 > 0,05 maka hasil akhir bisa di ketahui bahwa nilai residual bersifat normal.

\section{Uji Linearitas}

Hasil uji linearitas untuk masing-masing variabel penelitian disajikan berikut ini:

Tabel 5. Hasil Uji Linieritas

\begin{tabular}{|l|c|c|c|}
\hline \multicolumn{1}{|c|}{ Variabel } & Df & Sig & Keterangan \\
\hline $\begin{array}{l}\text { Minat } \\
\text { Mahasiswa } \\
\text { Hasil Belajar }\end{array}$ & $36: 27$ & 0,771 & Linear \\
\hline
\end{tabular}

Hasil tabel diatas menujukkan bahwa kalau signifikansi sebesar 0,771 > 0,05 bisa disimpulkan kalau ada ikatan yang linear antara Atensi Mahasiswa Dalam Pemakaian Google Classroom dengan Hasil Belajar Perawatan Kulit Wajah dengan Teknologi.

\section{Pengujian Hipotesis}

Berikut hipotesis nya:

Ha : "Atensi Mahasiswa Dalam Pemakaian Google Classroom mempengaruhi positif terhadap pencapaian nilai Belajar Perawatan Kulit Wajah dengan Teknologi".

Ho : "Atensi Mahasiswa Dalam Pemakaian Google Classroom tidak mempengaruhi positif terhadap pencapaian nilai Belajar Perawatan Kulit Wajah dengan Teknologi”.

\section{Analisis Korelasi (Product Moment)}

Bagan dibawah ini adalah hasil perhitungan korelasi Product Moment menggunakan SPSS 23 for Windows.

Tabel 6. Hasil Analisis Korelasi

\begin{tabular}{|l|c|c|}
\hline \multicolumn{1}{|c|}{ Variabel } & Nilai Hitung & Nilai Signifikansi \\
\hline $\begin{array}{l}\text { Minat Mahasiswa } \\
\text { dengan Hasil Belajar }\end{array}$ & 0,274 & 0,05 \\
\hline
\end{tabular}

Bersumber pada perhitungan diperoleh nilai signifikansi sebesar 0, 274 yang berarti lebih besar dari pada 0, 05. Sehingga bisa disimpulkan kalau Ho yang berbunyi:" Atensi Mahasiswa Dalam Pemakaian Google Classroom tidak 
mempengaruhi positif terhadap pencapaian nilai Belajar Perawatan Kulit Wajah dengan Teknologi” diterima. H1 yang berbunyi," Atensi Mahasiswa Dalam Pemakaian Google Classroom mempengaruhi positif terhadap pencapaian nilai belajar Perawatan Kulit Wajah dengan Teknologi” ditolak.

Buat mengenali besar ataupun kecil pengaruh tersebut, bisa mengacu pada pedoman dalam membagikan interpretasi koefisien korelasi dalam novel Sugiyono selaku berikut:

Tabel 7. Interpretasi Koefisien Korelasi

\begin{tabular}{|c|c|}
\hline Interval Koefisien & Tingkat Hubungan \\
\hline $0,00-0,199$ & Sangat Rendah \\
\hline $0,20-0,399$ & Rendah \\
\hline $0,40-0,599$ & Sedang \\
\hline $0,60-0,799$ & Kuat \\
\hline $0,80-1,000$ & Sangat Kuat \\
\hline
\end{tabular}

Pada hasil diatas diperoleh $\mathrm{rxy}=0,274$, berarti pengaruh Minat Mahasiswa Dalam Penggunaan Google Classroom terhadap Hasil Belajar Perawatan Kulit Wajah dengan Teknologi rendah.

\section{Analisis Regresi Linear Sederhana}

Dalam menguji besarnya ikatan Atensi Mahasiswa Dalam Pemakaian Google Classroom terhadap Hasil Belajar Perawatan Kulit Wajah dengan Teknologi digunakan analisis regresi simpel dengan memakai metode analisis statistik yang ada dalam, program SPSS 23 for Windows. Menanggapi rumusan permasalahan,“ Bagaimana ikatan atensi mahasiswa dalam pemakaian Google Classroom dengan hasil belajar perawatan kulit wajah dengan teknologi?”. Buat itu digunakan angkaangka selaku berikut:

Tabel 8. Hasil Uji Regresi Linear Sederhana

\begin{tabular}{|c|l|c|c|c|c|c|}
\hline \multicolumn{2}{|c|}{} & \multicolumn{2}{c|}{ Coeffecients } \\
\hline \multicolumn{2}{|c|}{ Model } & \multicolumn{2}{|c|}{$\begin{array}{c}\text { Unstandardized } \\
\text { Coeffecints }\end{array}$} & $\begin{array}{c}\text { Standardize } \\
\text { d } \\
\text { Coeffecients }\end{array}$ & T & Sig \\
\cline { 3 - 6 } & B & $\begin{array}{c}\text { Std. } \\
\text { Error }\end{array}$ & Beta & & \\
\hline \multirow{2}{*}{1} & (Constant) & 79.156 & .905 & & 87.488 & .000 \\
\cline { 2 - 6 } & $\begin{array}{l}\text { Minat } \\
\text { Mahasisw } \\
\text { a }\end{array}$ & .008 & .007 & .138 & 1.104 & .274 \\
\hline
\end{tabular}


Didapatkan hasil constant sebesar 79,156, akan tetapi nilai dari minat mahasiswa sebesar 0,008, sehingga kesamaan regresinya berikut ini:

$$
\begin{gathered}
\mathrm{Y}=\mathrm{a}+\mathrm{Bx} \\
\mathrm{Y}=79.156+(0,008)
\end{gathered}
$$

Dari kesamaan regresi ini menjelaskan bahwa setiap penambahan nilai Minat Mahasiswa Dalam Penggunaan Google Classroom maka akan mengurangi nilai Hasil Belajar Perawatan Kulit Wajah dengan Teknologi sebesar 0,008. Koefisien regresi diatas mengahsilkan nilai yang negatif sehingga dapat disimpulkan bahwa arah pengaruh variabel X terhadap Y adalah negatif. Berdasarkan nilai signifikansi, diperoleh nilai sebesar 0,274 > 0,05, sehingga diketahui bahwa Minat Mahasiswa Dalam Penggunaan Google Classroom tidak berpengaruh terhadap pencapaian nilai Belajar Perawatan Kulit Wajah menggunakan Teknologi.

\section{Uji t}

Tabel 9. Hasil Uji t

\begin{tabular}{|c|c|}
\hline \multicolumn{2}{|c|}{ Nilai Uji t } \\
\hline $\begin{array}{c}\text { Nilai Signifikansi } \\
\text { Variabel X dan Y }\end{array}$ & Keterangan \\
\hline $0,274>0,05$ & $\begin{array}{c}\text { HO diterima Ha } \\
\text { ditolak }\end{array}$ \\
\hline
\end{tabular}

Berdasarkan nilai signifikansi X terhadap $\mathrm{Y}(0,274>0,05)$. Oleh karena itu disimpulkan bahwa $\mathrm{H}_{0}$ diterima sedangkan $\mathrm{H}_{\mathrm{a}}$ tidak. Artinya tidak terdapat hubungan positif antara Minat Mahasiswa Dalam Penggunaan Google Classroom terhadap pencapaian nilai belajar Perawatan Kulit Wajah menggunakanTeknologi.

\section{Uji Koefisien Determinasi}

Hasil uji koefisien determinasi untuk masing-masing variabel penelitian:

Tabel 10. Koefisien Determinasi

\begin{tabular}{|c|c|}
\hline \multicolumn{2}{|c|}{ Koefisien Determinasi } \\
\hline $\mathrm{R}$ & $\mathrm{R}^{2}$ \\
\hline .138 & .019 \\
\hline
\end{tabular}

Pada bagan di atas dijelaskan jika nilai R Square sebanyak 0,019. Sehingga koefisien determinasi nya adalah:

$$
\begin{aligned}
& \mathrm{KP}=\mathrm{r}^{2} \times 100 \% \\
& \mathrm{KP}=0,019 \times 100 \% \\
& \mathrm{KP}=1,9 \%
\end{aligned}
$$


Hal ini menunjukkan bahwa variabel keinginan Mahasiswa Dalam Penggunaan Google Classroom berpengaruh positif terhadap pencapaian nilai Belajar Perawatan Kulit Wajah dengan Teknologi sebesar 1,9\% lalu sisanya 98,1\% tidak diikutkan pada penelitian ini.

\section{Pembahasan Hasil Penelitian}

Menguji interaksi antara Minat Mahasiswa Dalam Penggunaan Google Classroom Dengan pencapaian nilai Belajar Perawatan Kulit Wajah menggunakan Teknologi merupakan tujuan dari penelitian ini. Instrument yang akan dipakai untuk mengumpulkan data penelitian sebelumnya sudah dilakukan uji coba. Disimpulkan bahwa variabel Minat Mahasiswa Dalam Penggunaan Google Classroom terdiri menurut 4 indikator menggunakan 40 buah instrumen. Uji coba dilaksanakan secara online dilaksanakan pada bulan Maret 2021 sampai Juni 2021 di Universitas Negeri Jakarta menggunakan pelaksanaan Google Form menggunakan memakai 65 responden, menurut output uji coba tadi 34 buah soal dinyatakan valid $\& 6$ buah soal nir valid, lantaran diperoleh $r$ hitung $>r$ tabel.

Uji coba reliabilitas menunjukkan bahwa instrumen informasi lapangan Minat Mahasiswa Dalam Penggunaan Google Classroom bisa dikatakan reliabel, output buat variabel Minat Mahasiswa Dalam Penggunaan Google Classroom sebanyak 0,961 oleh karena itu output analisis uji coba validitas \& reliabilitas variabel Minat Mahasiswa Dalam Penggunaan Google Classroom, seluruh buah pertanyaan yg sudah diujikan pada responden sudah dinyatakan valid \& reliabel sebagai akibatnya bisa dipakai buat mengumpulkan data pada penelitian. Berdasarkan output analisis menggunakan hubungan product momen tidak menampakkan masih ada interaksi positif \& signifikan antara Minat Mahasiswa Dalam Penggunaan Google Classroom terhadap Hasil Belajar Perawatan Kulit Wajah menggunakan Teknologi. Berdasarkan perhitungan diperoleh nilai signifikansi sebanyak 0,274 yg berarti lebih akbar berdasarkan dalam 0,05. Sehingga bisa disimpulkan bahwa Ho yg berbunyi: "Minat Mahasiswa Dalam menggunakan Google Classroom berpengaruh positif terhadap pencapaian nilai Belajar Perawatan Kulit Wajah menggunakan Teknologi" diterima. Sebaliknya, "Minat Mahasiswa Dalam Penggunaan Google Classroom berpengaruh positif terhadap Hasil belajar Perawatan Kulit Wajah menggunakan Teknologi" ditolak. Sumbangan efektif diperoleh sebanyak 1,9\% sisanya 98,1\% tidak di masukan dalam penelitian ini.

Pernyataan ini dapat diartikan Ho diterima dan Ha ditolak sesuai dengan penelitian sebelumnya pada judul "Hubungan Minat Belajar Mahasiswa Dengan 
Hasil Belajar Mata Kuliah Rumpun Botani Pada Mahasiswa Program Studi Pendidikan Biologi Reguler FMIPA UNIMED Angkatan 2011" (Pinem \& Suriani, 2014).

Minat mahasiswa terdiri dari luar atau dalam, dalam membuat mereka tertarik pada sesuatu dan menyebabkan perasaan senang. Minat dalam menginginkan sesuatu tidak akan muncul dengan sendirinya. Minat tersebut akan muncul akibat pengaruh dua faktor ini, yaitu faktor internal (sesuatu yang membuat mahasiswa berminat) dan eksternal (sesuatu dari luar). Seseorang yang memiliki tingkat minat yang tinggi dalam pembelajaran dapat menghasilkan hasil belajar yang optimal namun dalam mata kuliah perawatan kulit wajah dengan teknologi yang dilakukan dengan Google Classroom. Selain Penggunaan Google Classroom bisa saja terdapat penunjang dari berbagai aspek dalam mempengaruhi pencapaian nilai belajar siswa.

Aplikasi Google Classroom memang didesain untuk memudahkan guru dan siswa dalam berinteraksi di sosial media. Aplikasi ini memungkinkan para pengajar untuk mengeksplorasi ide-ide sains mereka untuk siswa. Guru dapat fleksibel dalam hal waktu untuk berbagi penelitian ilmiah dan memberikan kuis-kuis mandiri kepada para murid, dan guru juga dapat membuka ruang diskusi online untuk siswa. Namun, satu kelemahan menggunakan Google Classroom adalah terbatasnya pilihan integrasi dengan Google Kalender, yang mempersulit pengaturan dokumen dan tenggat waktu.

Seperti penelitian ini, banyak faktor yang dapat mempengaruhi kinerja akademik. Dalam penelitian ini masih ditemukan faktor internal seperti aspek psikologis, meliputi persiapan dan perhatian, dan faktor ekstrinsik seperti aspek keluarga, termasuk suasana dan kondisi keluarga. Dalam kondisi pandemi saat ini, hasil belajar dapat dipengaruhi oleh faktor-faktor tersebut, karena ketika belajar membutuhkan sinyal yang baik, ponsel / laptop berfungsi dengan baik membutuhkan suasana tenang statis untuk memusatkan perhatian pada pembelajaran, dan gangguan ekonomi dapat menghambat pembelajaran. Dalam proses perawatan kulit wajah dengan teknologi, tidak hanya dibutuhkan rasa ingin tahu, tetapi juga persiapan dan perhatian. Dalam kursus ini, persiapan dan perhatian sangat penting karena membutuhkan pemahaman yang baik untuk mencapai hasil yang diinginkan. 


\section{SIMPULAN}

Survei ini dilakukan untuk mengetahui korelasi antara minat siswa menggunakan Google Classroom dengan hasil pencapaian nilai belajar perawatan kulit wajah menggunakan teknologi. Hal ini terlihat dari terdeteksi nya nilai signifikansi yang lebih besar dari 0,274 atau 0,05. Dari sini bisa diketahui bahwa Ho diterima dengan label "Minat siswa menggunakan Google Classroom tidak berdampak positif terhadap hasil belajar perawatan kulit wajah menggunakan teknologi." Di sisi lain, "Minat siswa menggunakan Google Classroom berpengaruh positif terhadap keberhasilan pembelajaran perawatan wajah menggunakan teknologi” ditolak. Kontribusi yang valid ditentukan menjadi 1,9\%, dengan sisa 98,1\% tidak diperiksa dalam penelitian ini.

Dalam penelitian ini masih terdapat beberapa faktor internal yang belum terdata, seperti aspek motivasi dan perhatian psikologis, serta aspek suasana keluarga dan ekonomi keluarga. Dalam lingkungan pandemi saat ini, hasil belajar dapat dipengaruhi oleh faktor-faktor ini. Hal ini karena jika belajar membutuhkan sinyal yang baik, ponsel/laptop yang berfungsi membutuhkan suasana yang tenang untuk fokus belajar, dan gejolak ekonomi dapat menghambat belajar. Perawatan wajah berbasis teknologi tidak hanya membutuhkan minat belajar, tetapi juga persiapan dan perhatian. Persiapan dan perhatian sangat penting dalam kursus ini karena mereka perlu dipahami seperti yang diharapkan.

\section{DAFTAR PUSTAKA}

Arikunto, S. (2012). Prosedur Penelitian. Jakarta: Rineka Cipta.

Darmawani, C. D. (2015). Strategi Adaptasi Pelaksanaan Pendidikan Anak

Pengungsi Di Lokasi Pengungsian Paroki Gereja Katolik Kabanjahe Kabupaten

Karo. Doctoral Dissertation, UNIMED.

Fauzan, A., Thamrin, Sholikhin, A., \& Rugayah. (2020). Pemanfaatan Google

Classroom Sebagai Media Pembelajaran Interaktif Di Tengah Dampak Penyakit

Virus Corona 19 Bagi Pengajar. Jurnal Borneo Akcaya, 6(1), 93-102.

https: / / doi.org/10.51266/borneoakcaya.v6i1.159

Marasmita, D. (2019). Pengembangan Media Pembelajaran E-learning Berbasis

Google Classroom Untuk Meningkatkan Motivasi Belajar Siswa Pada Mata

Pelajaran Ekonomi Kelas X Di SMA Negeri 1 Nogosari. Doctoral Dissertation, Universitas Muhammadiyah Surakarta, 1-8.

Nurkholis, N. (2020). Dampak Pandemi Novel-Corona Virus Disiase (Covid-19)

Terhadap Psikologi Dan Pendidikan Serta Kebijakan Pemerintah. Jurnal PGSD, 
6(1), 39-49. https://doi.org/10.32534/jps.v6i1.1035

Pinem, M. D., \& Suriani, C. (2014). Hubungan Minat Belajar Mahasiswa Dengan Hasil Belajar Mata Kuliah Rumpun Botani Pada Mahasiswa Program Studi Pendidikan Biologi Reguler Fmipa Unimed Angkatan 2011. Prosiding Seminar Nasional Biologi Dan Pembelajarannya, 648-653.

Setiawan, A. R. (2020). Lembar Kegiatan Literasi Saintifik untuk Pembelajaran Jarak Jauh Topik Penyakit Coronavirus 2019 (COVID-19). Edukatif : Jurnal Ilmu Pendidikan, 2(1), 28-37. https: // doi.org/10.31004/edukatif.v2i1.80 Sugiyono. (2016). Metode Penelitian Bisnis (Pendekatan Kuantitatif, Kualitatif, Kombinasi dan R\&D). In Metodelogi Penelitian. Bandung: Alfabeta.

Wartini, S. (2012). Peningkatan minat belajar seni tari melalui hypnoteaching di SD Negeri 1 Prambanan Klaten. Jurnal Minat Belajar, 6-32.

http:/ / dx.doi.org/10.26740/jp.v2n2.

Windayani, N. R., \& Ihsani, A. N. N. (2014). Peningkatan Hasil Belajar Pada Rias Wajah Sehari-Hari Melalui Multimedia Pembelajaran Interaktif di SMK N 1 Tegal. Journal of Beauty and Beauty Health Education, 3(1), 1-7. https:/ / doi.org/ 10.15294/bbhe.v3i1.7776 